\title{
Converging Newton Method with an Inflection Point of a Function
}

\author{
Ridwan PANdiya ${ }^{1}$, Ismail Bin Mohd ${ }^{2}$ \\ ${ }^{1}$ Program Studi Informatika, ST3 Telkom, Jl. DI Panjaitan No. 128 Purwokerto 53147, \\ ridwanpandiya@st3telkom.ac.id \\ ${ }^{2}$ Fakulti Sains Komputer dan Teknologi Maklumat, Universiti Putra Malaysia, 43400 \\ UPM Serdang Selangor Darul Ehsan, \\ ismail_ayah_irma@yahoo.com
}

\begin{abstract}
Abstrak
Metode-metode dalam pencarian akar sebuah fungsi nonlinear telah banyak diteliti. Para matematikawan berusaha meneliti bagaimana menentukan titik awal yang baik ketika mengimplementasikan metode-metode pencarian akar sebuah persamaan, dan salah satu metode yang paling sering digunakan adalah metode Newton. Metode ini menghasilkan barisan bilangan yang konvergen ke satu akar dengan asumsi titik awal yang digunakan cukup dekat kepada akar yang akan dicari. Kata cukup dekat mengindikasikan bahwa penentuan titik awal yang tepat belum banyak diketahui. Artikel ini menjawab pertanyaan seberapa dekat tadi melalui serangkaian analisa hubungan antara titik infleksi dari suatu fungsi nonlinear satu variabel dengan kekonvergenan metode Newton. Tujuan artikel ini adalah mengilustrasikan lingkungan dari titik infleksi apabila kita gunakan sebagai titik awal maka akan selalu konvergen ke satu akar terdekat.

Kata kunci: Metode Newton, akar-akar persamaan nonlinear, titik infleksi, kelengkungan, jari-jari. kelengkungan
\end{abstract}

\begin{abstract}
Root finding methods have been studied by many mathematicians. They struggled in obtaining the appropriate starting point when implementing root finding methods, and one of the most famous and applicable is Newtons method. This iterative method produces sequence that converges to a desired solution with the assumption that the starting point is close enough to a solution. The word close enough indicates that the exact starting point is not well known. This paper comes to answer that question through analyzing the relationship between inflection points of one-dimensional non-linear function with the convergence of Newtons method. Our purpose is to illustrate that the neighborhood of an inflection point of a function never fails to bring the Newtons method convergent to a desired solution.

Keywords : Newtons method, zero of function, inflection point, curvature, radius of curvature.
\end{abstract}

2000 Mathematics Subject Classification: 65B99

Received: 2017-04-13, accepted: 2017-08-15 


\section{INTRODUCTION}

Newton method is a well-known method for finding roots of a function. This method firstly initiated by Newton in 1669 for finding a root of a polynomial equation and generalized by Raphson several years later. Assume that:

$$
f(x) \in C^{2}
$$

be a nonlinear function with the roots $x_{i}^{*}, i=1,2, \ldots, n$, and $x^{0}$ be the initial guess of a root of (1). The iterates (2) :

$$
x_{i+1}=x_{i}-\frac{f\left(x_{i}\right)}{f^{\prime}\left(x_{i}\right)}, i=1,2,3, \ldots
$$

is well-defined called Newtons method and $x_{i}$ will converge to the root of (1) when starting with a good enough initial guess and it converges quadratically [Sli and Mayers (2003)]. Then define the basin of $x^{*}$ to be the set of points where Newton method will converge to $x^{*}$ if one of the points contains in the basin is taken as an initial guess. An appropriate starting point can be inferred from Theorem 1 taken form [Burden and Faires, 2011].

Theorem 1

Let $f \in C^{2}[a, b]$. If $p \in(a, b)$ is such that $f(p)=0$ and $f^{\prime}(p) \neq 0$ then there exists a $\delta>0$ such that Newtons method generates a sequence $\left\{p_{n}\right\}_{n=1}^{\infty}$ converging to $p$ for any initial approximation $p_{0} \in[p-\delta, p+\delta]$.

The $\delta$ stated in Theorem 1 indicates that Newtons method convergences is depends on the value of $\delta$.

Some literature only discusses the efficiency and the order of convergence of the methods than to analyze the existence of the basin of a solution, such as in Fang et al. [2008], they presented a modified Newton method which has efficiency index equal to $\sqrt[4]{5}$ which is better than the original Newton method $\sqrt{2}$, while in Sharma et al. [2011], they derived some methods of order four for solving nonlinear equation where the efficiency index is 1.587, and many other literatures. But, again, the efficiency of Newton methods convergence depends on an appropriate initial guess. There are several Newton methods bad behaviors caused by the inappropriate initial guess [Kornerup and Muller, 2006; Chun, 2005; Babolian and Biazar, 2002; Abbasbandy, 2003], and here we have summarized those bad behaviors taken from Wood [1999]. First, if the iteration $x_{i}$ has zero slopes, and then $f\left(x_{i}\right) / f^{\prime}\left(x_{i}\right)$ is undefined and the tangent line never intersects to the -axis, consequently, $x_{i+1}$ is undefined. The second obstacle is the oscillation phenomenon. Oscillation happened when the sequence of iteration $\left\{x_{i}\right\}$ gets trapped between two or more values. For example, consider the equation $f(x)=0$ with $f(x)=x^{3}-2 x+2$.

The Newtons method iteration with $x_{0}=0$ and $x_{0}=-5$ are taken as an initial guess is summarized in Table 1 as follows.

\begin{tabular}{|c|c|c|}
\hline$i$ & & \\
\hline 0 & 0 & -5 \\
\hline 1 & 1 & -3.45205 \\
\hline 2 & 0 & -2.49701 \\
\hline 3 & 1 & -1.9837 \\
\hline 4 & 0 & -1.79619 \\
\hline 5 & 1 & -1.7698 \\
\hline
\end{tabular}

Table 1. Oscillation phenomenon of Newtons method

$f(x)$ has a single root at $x^{*}=-1.76929$. It can be seen in Table 1 that the iteration oscillates between 0 and 1 when $x_{0}=0$ has been taken as initial guess, while the initial guess $x_{0}=-5$ brings the iteration to the solution. 
Third bad behavior of Newton method happens when the initial guess is not close enough to the desired solution. This situation may bring the sequence $\left\{x_{i}\right\}$ diverge from the solution $x^{*}$. See Table 2 below.

Table 2. Divergence of Newton method

\begin{tabular}{ccc}
\hline$i$ & $x_{i}$ \\
\hline 0 & -0.3 & 3 \\
1 & -0.0692308 & 4.5 \\
2 & -0.00448257 & 5.78571 \\
3 & $-2.00037 \mathrm{e}-005$ & 6.99467 \\
4 & $-4.00142 \mathrm{e}-010$ & 8.16148 \\
5 & $-1.60114 \mathrm{e}-019$ & 9.30112 \\
\hline
\end{tabular}

Table 2 is the first five iteration of Newton method for solving the equation $f(x)=x e^{-x}$ starting at $x_{0}=-0.3$ and $x_{0}=3$. First initial guess $x_{0}=-0.3$ brings into being speedily converging sequence of iterations to the solution that is $x=0$. If $x_{0}=3$, the iterations vanish to infinity.

Those several bad behaviors of Newtons method bring in the inspiration of basins of attraction to initial guess $x_{0}$. This paper concerns on investigating and analyzing the best initial guess for which Newtons method will never be failed for converging to the desired solution. Several testing example are given to see the influence of curvature at point of inflection to the convergence of Newton method. The results lead us to a hypothesis and ultimately produce a theorem.

The goal of the paper is to find the basin of attraction of Newton method through analyzing relation between point of inflection and curvature of nonlinear function. The numerical experiments may be expected to give a good sense in building a theoretical framework and at the end, a theorem of basin of attraction of Newton method will be yield.

The rest of the paper is organized as follows. In section 2 , the theory of curvature and point of inflection and also the relationship between the neighborhood of point of inflection point and curvature at that point will be described. In section 3 several testing examples are studied. Section 4 will present a theorem. Finally, some concluding remarks are made in Section 5 .

\section{Relation Between Curvature and Point of Inflection}

Before any further, the theory of curvature and the point of inflection will be discussed firstly. To give a good sense, now consider Figure 1. Figure 1 shows the graph of $f(x)$, where $(a, f(a))$ and $(b, f(b))$ are two points on the graph, and the tangents to the graph at these points. The measure of the angle formed by the two tangents is $c$, and the distance along the graph between $(a, f(a))$ and $(b, f(b))$ is $s$. The expression $c / s$ is the average rate of bending of the curve between $(a, f(a))$ and $(b, f(b))$ [Lightstone, 1965], which is better known as curvature. In Purcel and Varberg [1984], they called curvature is a measure how sharply a curve bends. Following curvature definition and theorem will be very useful.

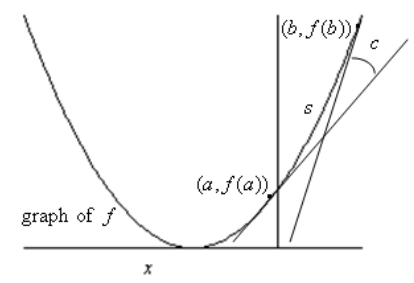

Figure 1. Tangent line of a function at a point 
Definition 1. [Lightstone (1965)]. (1) Let the curve be given by the differentiable vector function $f(t)=f_{1}(t)+f_{2}(t)$. Let $\phi(t)$ denotes the direction of $f^{\prime}(t)$. Then the curvature of , denoted by $\kappa(t)$, is the absolute value of the rate of change of direction with respect to arc length $(s)$, that is

$$
\kappa(t)=\left|\frac{d \phi}{d s}\right|
$$

The radius of curvature $\rho(t)$ is defined by

Theorem 2. [Lightstone (1965)]. If $C$ is a curve with equation $y=f(x)$ where $f$ is twice differentiable, then

$$
\kappa(t)=\frac{\left|f^{\prime \prime}(x)\right|}{\left(1+\left(f^{\prime}(x)\right)^{2}\right)^{3 / 2}}
$$

It is clearly from Theorem 2 that line must have curvature 0 and a sharply turning curve should have a large curvature. Curvature will also 0 if $f^{\prime \prime}(x)=0$ and it has been known that points where $f^{\prime \prime}(x)=0$ or where $f^{\prime \prime}(x)$ does not exist are the nominees for point of inflection. The formal definition of point of inflection is as follows.

Definition 2. [Purcel and Varberg (1984)]. Let $f$ be continuous at $c$. Point $(c, f(c))$ an inflection point of a graph of $f$ if $f$ is concave up on one side of $c$ and concave down on the other side.

From the remark that line must have 0 curvature and Definition 2, we can intuitively conclude that curvature of a function at point of inflection is 0 , and curvature of a function at the neighborhood of point of inflection are almost 0 . Then, it can be said that the graph of a neighborhood of point of inflection where the curvature are very close to 0 is almost straight line. This conclusion can be used for solving the drawback of the convergence of Newton method since for most non convex function, Newton method will fail to obtain the closest solution and the iteration sometimes goes out far from the solution because the process depend on the tangent line of each iteration. The more the curve blends (large curvature), the more the iteration goes out. The complete discussion will be given in Section 4. For non convex function, the tangent line at the neighborhood of point of inflection (almost line) will leads the iterations to the closest root rather than tangent line at the other points. Before spilling our intuitive thought becomes a theorem, some testing examples will be given in Section 3 .

\section{Numerical EXPERIMENTS}

In this section, some experiments in which three test examples have been used for showing that the neighborhood of point of inflection never fails for obtaining the nearest root of nonconvex problems. In this experiment, it is assumed that the points of inflection have been known in advance which will be used as the initial guesses when employing Newton method. The idea how to find inflection points of a function is given in [Pandiya, 2013] The three test examples and their graphs taken from (Wen et al. [2012]; Pandiya [2013] are given in Figure 2.

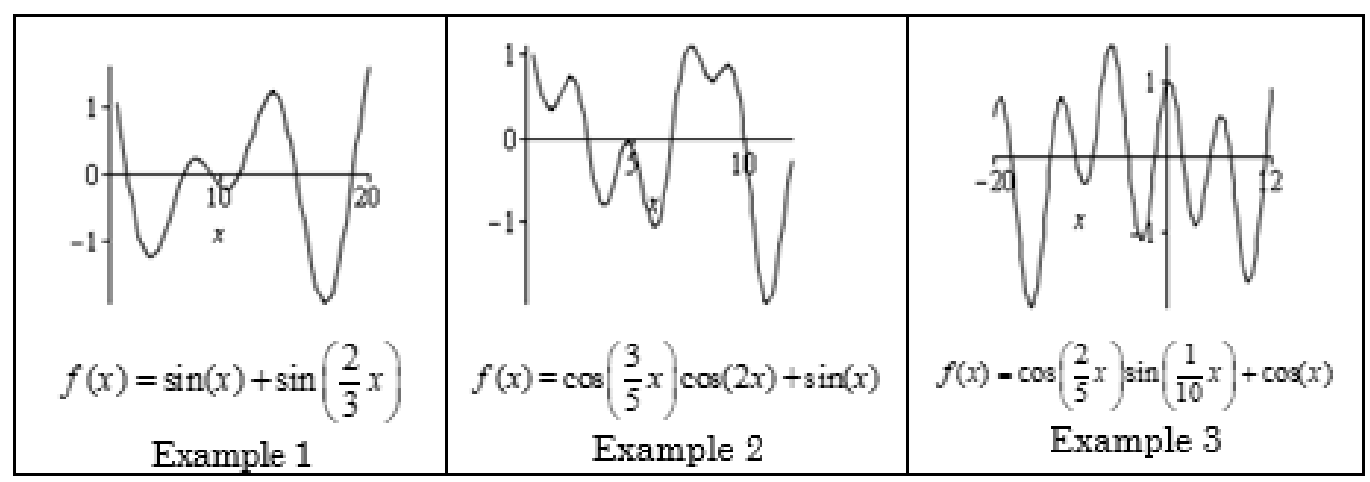




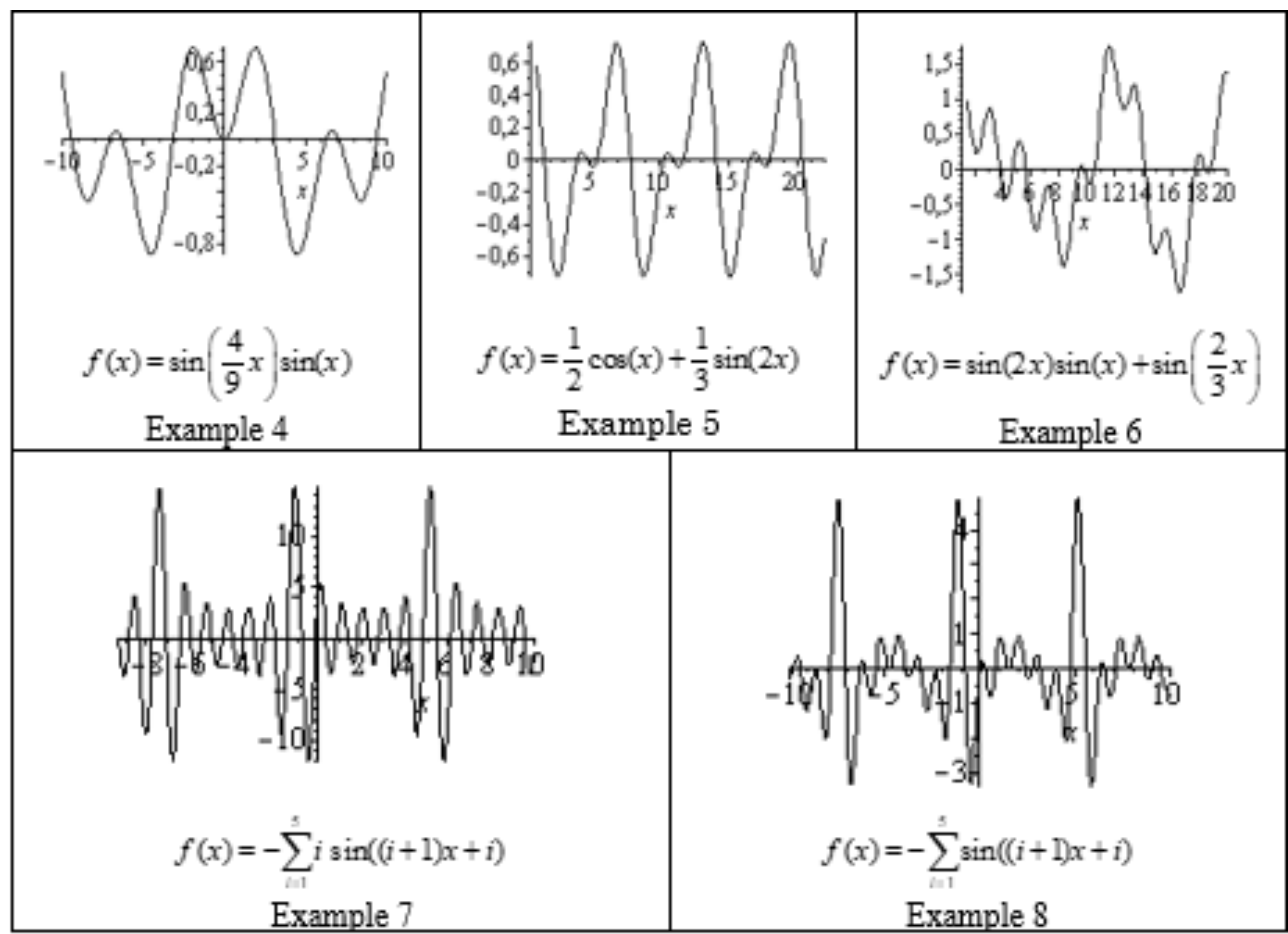

FIGURE 2. Graph of the test functions

The numerical results are summarized in Table 3. It has been mentioned before that the tangent line at the neighborhood of point of inflection will guide the iterations of Newton method into the convergence. In Table 3, the second column indicates points of inflection for the three examples which are also initial points in operating Newton method.

Table 3. Numerical Results

\begin{tabular}{cccc}
\hline Example & Point of inflection & Root & Value of the root \\
\hline 1 & 3.47428 & 3.76991 & $-1.50704 \mathrm{e}-016$ \\
6.73129 & 7.53982 & $-1.01481 \mathrm{e}-016$ \\
9.42478 & 9.42478 & $1.22461 \mathrm{e}-016$ \\
12.1183 & 11.3097 & $-2.71918 \mathrm{e}-016$ \\
15.3753 & 15.0796 & $7.69079 \mathrm{e}-016$ \\
18.8496 & 18.8496 & $-1.22461 \mathrm{e}-015$ \\
2 & & & \\
& 2.98167 & 2.95411 & $1.62441 \mathrm{e}-016$ \\
& 6.71031 & 6.71118 & $-1.89519 \mathrm{e}-016$ \\
& 10.1792 & 9.93822 & $-1.51197 \mathrm{e}-015$ \\
& & & \\
& -17.4012 & -17.9378 & $1.50541 \mathrm{e}-016$ \\
& -14.0147 & -13.4781 & $-6.18754 \mathrm{e}-016$ \\
& -10.9092 & -10.5816 & $8.93925 \mathrm{e}-016$ \\
& -7.97863 & -8.66132 & $6.05798 \mathrm{e}-016$ \\
& -4.75438 & -4.59502 & $1.11808 \mathrm{e}-017$ \\
& -1.50495 & -1.44966 & $6.19554 \mathrm{e}-017$ \\
& 1.64102 & 1.70283 & $3.91533 \mathrm{e}-017$ \\
& & &
\end{tabular}


78 Pandiya and Mohd, JMI Vol 13 No 2 Okt 2017, pp. 73-81,doi:10.24198/jmi.v13.n2.11785.73-81

Table 3. Numerical Results

\begin{tabular}{|c|c|c|c|}
\hline Example & Point of inflection & Root & Value of the root \\
\hline & 4.66632 & 4.88978 & 2.5247 e-016 \\
\hline & 7.73771 & 7.16913 & -2.27954 e-016 \\
\hline & 11.0725 & 11.2033 & -9.08453 e-016 \\
\hline \multirow[t]{9}{*}{4} & -7.56218 & -7.06858 & $8.65927 \mathrm{e}-017$ \\
\hline & -5.53995 & -6.28319 & $-8.3768 \mathrm{e}-017$ \\
\hline & -3.2392 & -3.14159 & $1.206 \mathrm{e}-016$ \\
\hline & -1.00024 & $-1.18078 \mathrm{e}-0162$ & 0 \\
\hline & 1.00024 & $1.18078 \mathrm{e}-0162$ & 0 \\
\hline & 3.2392 & 3.14159 & $1.206 \mathrm{e}-016$ \\
\hline & 5.53995 & 6.28319 & $-8.3768 \mathrm{e}-016$ \\
\hline & 7.56218 & 7.06858 & $8.65927 \mathrm{e}-017$ \\
\hline & 9.72208 & 9.42478 & $-3.18162 \mathrm{e}-016$ \\
\hline \multirow[t]{12}{*}{5} & 3.33021 & 3.98965 & $5.55112 \mathrm{e}-017$ \\
\hline & 4.71239 & 4.71239 & $3.06152 \mathrm{e}-017$ \\
\hline & 6.09457 & 5.43512 & $5.55112 \mathrm{e}-017$ \\
\hline & 7.85398 & 7.85398 & $3.57177 \mathrm{e}-016$ \\
\hline & 9.61339 & 10.2728 & 0 \\
\hline & 10.9956 & 10.9956 & $7.14354 \mathrm{e}-017$ \\
\hline & 12.3778 & 11.7183 & $2.22045 \mathrm{e}-016$ \\
\hline & 14.1372 & 14.1372 & $6.42918 \mathrm{e}-016$ \\
\hline & 15.8966 & 16.556 & $-5.55112 \mathrm{e}-017$ \\
\hline & 17.2788 & 17.2788 & $-1.83804 \mathrm{e}-016$ \\
\hline & 18.6609 & 18.0015 & $-3.33067 \mathrm{e}-016$ \\
\hline & 20.4204 & 20.4204 & $-1.14376 \mathrm{e}-015$ \\
\hline \multirow[t]{10}{*}{6} & 4.71239 & 4.71239 & $-2.44921 \mathrm{e}-016$ \\
\hline & 3.65426 & 3.78726 & $4.06847 \mathrm{e}-016$ \\
\hline & 5.77052 & 5.63752 & $-3.18051 \mathrm{e}-016$ \\
\hline & 8.94451 & 9.42478 & $-2.44921 \mathrm{e}-016$ \\
\hline & 9.9267 & 9.79544 & $-1.03406 \mathrm{e}-016$ \\
\hline & 10.9683 & 10.5652 & $-9.45153 \mathrm{e}-016$ \\
\hline & 14.1372 & 14.1372 & $1.46953 \mathrm{e}-015$ \\
\hline & 17.306 & 17.7091 & $1.61145 \mathrm{e}-015$ \\
\hline & 18.3476 & 18.4789 & $-1.02692 \mathrm{e}-015$ \\
\hline & 19.3298 & 18.8496 & $-4.89843 \mathrm{e}-016$ \\
\hline \multirow[t]{17}{*}{7} & -8.78099 & -8.79418 & $-1.02141 \mathrm{e}-014$ \\
\hline & -8.25976 & -8.33823 & $3.55271 \mathrm{e}-015$ \\
\hline & -7.6897 & -7.73795 & $4.44089 \mathrm{e}-016$ \\
\hline & -7.09257 & -7.06931 & $-3.61933 \mathrm{e}-014$ \\
\hline & -6.50838 & -6.42988 & $-2.66454 \mathrm{e}-015$ \\
\hline & -5.9699 & -5.93072 & $1.02141 \mathrm{e}-014$ \\
\hline & -5.46785 & -5.4615 & $-1.19904 \mathrm{e}-014$ \\
\hline & -4.97098 & -4.94554 & $6.21725 \mathrm{e}-015$ \\
\hline & -4.47764 & -4.48737 & $-1.58207 \mathrm{e}-014$ \\
\hline & -3.9846 & -3.97618 & $1.77636 \mathrm{e}-015$ \\
\hline & -3.49188 & -3.50505 & $-3.33067 \mathrm{e}-015$ \\
\hline & -2.996 & -3.01437 & $-4.44089 \mathrm{e}-016$ \\
\hline & -2.4978 & -2.51099 & $3.55271 \mathrm{e}-015$ \\
\hline & -1.97658 & -2.05504 & $-1.77636 \mathrm{e}-015$ \\
\hline & -1.40652 & -1.45477 & $6.21725 \mathrm{e}-015$ \\
\hline & -0.809383 & -0.78612 & $-3.10862 \mathrm{e}-015$ \\
\hline & -0.225195 & -0.146693 & $1.77636 \mathrm{e}-015$ \\
\hline
\end{tabular}


Table 3. Numerical Results

\begin{tabular}{|c|c|c|c|}
\hline Example & Point of inflection & Root & Value of the root \\
\hline & 0.313287 & 0.352464 & $-4.44089 \mathrm{e}-016$ \\
\hline & 0.815333 & 0.82169 & $-3.10862 \mathrm{e}-015$ \\
\hline & 1.3122 & 1.33765 & 7.99361e-015 \\
\hline & 1.80555 & 1.79582 & $7.38298 \mathrm{e}-015$ \\
\hline & 2.29859 & 2.30701 & $-1.24137 \mathrm{e}-014$ \\
\hline & 2.7913 & 2.77813 & $2.44249 \mathrm{e}-015$ \\
\hline & 3.28718 & 3.26882 & $-1.42109 \mathrm{e}-014$ \\
\hline & 3.78538 & 3.77219 & $8.88178 \mathrm{e}-016$ \\
\hline & 4.30661 & 4.22814 & $4.44089 \mathrm{e}-015$ \\
\hline & 4.8667 & 4.82842 & $1.59872 \mathrm{e}-014$ \\
\hline & 5.4738 & 5.49707 & $-3.10862 \mathrm{e}-015$ \\
\hline & 6.05799 & 6.13649 & $4.44089 \mathrm{e}-015$ \\
\hline & 6.59647 & 6.63565 & $-2.22045 \mathrm{e}-015$ \\
\hline & 7.09852 & 7.10488 & $4.88498 \mathrm{e}-015$ \\
\hline & 7.59539 & 7.62084 & $-4.44089 \mathrm{e}-016$ \\
\hline & 8.08873 & 8.079 & $2.498 \mathrm{e}-015$ \\
\hline & 8.58177 & 8.59019 & $-2.64927 \mathrm{e}-014$ \\
\hline & 9.07449 & 9.06132 & $-3.77476 \mathrm{e}-015$ \\
\hline & 9.57037 & 9.552 & $-7.54952 \mathrm{e}-015$ \\
\hline \multirow[t]{36}{*}{8} & -8.79099 & -8.60398 & $8.20145 \mathrm{e}-016$ \\
\hline & -8.30131 & -8.53982 & $-1.68745 \mathrm{e}-015$ \\
\hline & -7.71735 & -7.81858 & $4.79548 \mathrm{e}-015$ \\
\hline & -7.07903 & -7.03319 & $-4.67072 \mathrm{e}-015$ \\
\hline & -6.46563 & -6.24779 & $1.85789 \mathrm{e}-015$ \\
\hline & -5.9479 & -6.02655 & $-7.90844 \mathrm{e}-016$ \\
\hline & -5.46144 & -5.46239 & $-2.2112 \mathrm{e}-015$ \\
\hline & -4.9577 & -4.76991 & $-2.24809 \mathrm{e}-016$ \\
\hline & -4.48237 & -4.67699 & $-2.36985 \mathrm{e}-016$ \\
\hline & -3.98047 & -3.89159 & $9.11001 \mathrm{e}-017$ \\
\hline & -3.49857 & -3.51327 & $2.28658 \mathrm{e}-016$ \\
\hline & -3.00749 & -3.10619 & $5.44812 \mathrm{e}-016$ \\
\hline & -2.5078 & -2.3208 & $2.06269 \mathrm{e}-016$ \\
\hline & -2.01813 & -2.25664 & $-5.73543 \mathrm{e}-017$ \\
\hline & -1.43417 & -1.5354 & $5.7479 \mathrm{e}-016$ \\
\hline & -0.795842 & -0.75 & $6.06069 \mathrm{e}-017$ \\
\hline & -0.182445 & 0.0353982 & $-2.87639 \mathrm{e}-016$ \\
\hline & 0.335283 & 0.256637 & $7.54334 \mathrm{e}-016$ \\
\hline & 0.821742 & 0.820796 & $1.16579 \mathrm{e}-016$ \\
\hline & 1.32549 & 1.51327 & $2.48862 \mathrm{e}-015$ \\
\hline & 1.80081 & 1.60619 & $6.67977 \mathrm{e}-016$ \\
\hline & 2.30271 & 2.39159 & $4.2788 \mathrm{e}-016$ \\
\hline & 2.78461 & 2.76991 & $-5.42931 \mathrm{e}-015$ \\
\hline & 3.2757 & 3.17699 & $-1.56412 \mathrm{e}-015$ \\
\hline & 3.77538 & 3.96239 & $2.95255 \mathrm{e}-016$ \\
\hline & 4.26506 & 4.02655 & $6.25422 \mathrm{e}-016$ \\
\hline & 4.84902 & 4.74779 & $-2.27574 \mathrm{e}-015$ \\
\hline & 5.48734 & 5.53319 & $4.6254 \mathrm{e}-015$ \\
\hline & 6.10074 & 6.31858 & $-3.96818 \mathrm{e}-016$ \\
\hline & 6.61847 & 6.53982 & $1.05276 \mathrm{e}-015$ \\
\hline & 7.10493 & 7.10398 & $4.45932 \mathrm{e}-016$ \\
\hline & 7.60867 & 7.79646 & $2.7723 \mathrm{e}-016$ \\
\hline & 8.084 & 7.88938 & $4.54779 \mathrm{e}-015$ \\
\hline & 8.5859 & 8.67478 & $-2.22378 \mathrm{e}-015$ \\
\hline & 9.0678 & 9.0531 & $-1.06642 \mathrm{e}-015$ \\
\hline & 9.55888 & 9.46018 & $-1.89676 \mathrm{e}-015$ \\
\hline
\end{tabular}


In fact, analytically, point of inflection point cannot directly be used as initial point when employing Newton method. However, points of inflection given in Table 3 are obtained by programming (numerically), so they are actually the neighborhood of point of inflection. Table 3 shows that our hypothesis likelihood of successful outcomes. The intuitive discussion and the results of numerical experiment will be poured into a theorem given in the next section.

\section{The Use of Inflection Point for Converging Newton Method}

If Newton method is implemented to a straight line, then the root will be obtained only by one iteration from every initial guess. This fact together with the remark of curvature that the straight line has the 0 value of curvature leads our intuitive thoughts that every twice continuous differentiable function has straight line part and every point lies at that straight line part will always converge to the nearest solution.

Theorem 3. If (1) $f \in C^{2}[a, b],(2) f$ has minimum point $(m, f(m))$, maximum point $(M, f(M))$ and $f(m) . f(M)<0,(3) c$ is a point of inflection between $m$ and $M$ from any starting point $x_{0} \in(c-\epsilon, c+\epsilon)(\epsilon>0)$

Proof. Since $f(m) . f(M)<0$, then there is $\alpha \in R$ where $f(\alpha)=0$ between $m$ and $M$. If $\epsilon>0$ is made very small and $x_{0} \in((c-\epsilon, c+\epsilon))$ then $\left|x_{0}-c\right| \leq 0$. Therefore $c-\epsilon \leq x_{0} \leq c+\epsilon$. If $\epsilon \rightarrow 0$, then $x_{0} \rightarrow c$. By induction $x_{0}=c$ thus $f^{\prime \prime}\left(x_{0}\right)=f^{\prime \prime}(c)=0$.

The value of curvature at $x_{0}$ is as follows.

$$
\kappa\left(x_{0}\right)=\frac{\left|f^{\prime \prime}\left(x_{0}\right)\right|}{\left.1+\left(f^{\prime}(x)\right)^{2}\right)^{3 / 2}}=0
$$

Since $\kappa\left(x_{0}\right)=0$, the graph of $f$ at $x_{0}$ is a straight line, then Newton method will converge to the nearest root of $f$ between $m$ and $M$.

\section{Conclusion}

In this paper, a theorem for converging Newton method is presented. This theorem was constructed by the relationship between point of inflection and curvature. From numerical results and Theorem 3, it can be concluded that the neighborhood of point of inflection between a minimum and maximum point will converge to the nearest root of nonlinear function.

\section{DAFtar Pustaka}

[1] Abbasbandy, S., 2003, Improving Newton-Raphson method for nonlinear equations by modified adomian decomposition method, Applied Mathematics and Computation Volume 145, Pages 887893.

[2] Babolian, E., Biazar, J., 2002, Solution of nonlinear equations by modified adomian decomposition method, Applied Mathematics and Computation Volume 132, Pages 167172.

[3] Burden, R. L., and Faires, J. D., Numerical Analysis, Cengage Learning, USA, 2011.

[4] Chun, C., 2005, Iterative methods improving Newtons Method by the decomposition method, Computer \& Mathematics with Applications Volume 50, Pages 15501568.

[5] Fang, L., Sun, L., He, G., 2008, An efficient Newton-type method with fifth-order convergence for solving nonlinear equations, Computational and Applied Mathematics Volume 27, Pages 269274.

[6] Kornerup, P., Muller, J. M., 2006, Choosing starting values for certain Newton-Raphson iterations, Theoretical Computer Science Volume 351, Pages 101110.

[7] Lightstone, A. H., Concepts of Calculus I, Harper \& Row, 1965.

[8] Pandiya, R., An efficient method for determining all the extreme points of function with one variable. M.Sc thesis, Universiti Malaysia Terengganu, 2013.

[9] Purcell, E. J., and Varberg, D., Calculus with Analytic Geometry, Prentice-Hall, Inc., Englewood Cliffs, NJ, 1984.

[10] Sharma, J. R., Guha, R. K., Sharma, R., 2011, Some modified newtons methods with fourth-order convergence, Advances in Applied Science Research Volume 2, Pages 240247.

[11] Sli, E. and Mayers, D., An Introduction to Numerical Analysis, Cambridge University Press, UK, 2003. 
[12] Wen, G. K., Mamat, M. B., Mohd, I. B., Dasril, Y. B., 2012, Global optimization with nonparametric filled function, Far East Journal of Mathematical Sciences Volume 61, Pages 51 -64.

[13] Wood, A., Introduction to Numerical Analysis, Addison Wesley Longman, New York, 1999. 
82 Pandiya and Mohd, JMI Vol 13 No 2 Okt 2017, pp. 73-81,doi:10.24198/jmi.v13.n2.11785.73-81 